\title{
Hydrological responses and soil erosion potential of abandoned cropland in the Loess Plateau, China
}

\author{
Yu Liu ${ }^{a}$, Bojie Fu ${ }^{\text {a,* }}$, Yihe Lü ${ }^{a}$, Zhi Wang ${ }^{b}$, Guangyao Gao ${ }^{a}$ \\ a State Key Laboratory of Urban and Regional Ecology, Research Centre for Eco-Environmental Sciences, Chinese Academy of Sciences, Beijing 100085, China \\ b Department of Earth and Environmental Sciences, California State University, Fresno, CA 93740, USA
}

\section{A R T I C L E I N F O}

Article history:

Received 4 July 2010

Received in revised form 6 September 2011

Accepted 7 October 2011

Available online 14 October 2011

\section{Keywords:}

Hydrological response

Soil erosion

Scale effect

Revegetation

The Loess Plateau

\begin{abstract}
A B S T R A C T
Recent changes in hydrological processes and soil erosion in the Loess Plateau, China, are immediate responses to cropland abandonment for revegetation, which lead to a long-term decrease in runoff generation and soil erosion. However, detailed hydrological responses and soil erosion changes have not been clearly evaluated. In this study, two issues were focused on the plot scale. The first issue relates to changes in vegetation cover and soil properties during the early stages of revegetation. Given the occurrence of soil compaction, it was hypothesized that runoff increased during this period and the soil erosion did not significantly decline, even though vegetation increased. The second issue is the effect of scale on runoff and soil erosion. Three plot groups of three vegetation types and two restoration stages were established for comparative experiments. The results from these experiments confirmed that the soil compaction occurred during revegetation in this region. Greater runoff was produced in plot group that experienced both a longer restoration time and with higher vegetation cover (such as Groups 2 and 3 in this study) than that with a shorter restoration time and lower vegetation cover (Group 1). In addition, the total soil loss rates of all plot groups were rather low and did not significantly differ from each other. This indicates that a reduction in runoff generation and soil erosion, as a result of revegetation, was limited in the early stages of restoration following the cropland abandonment. With increasing plot area, the runoff coefficient decreased for the plot group with a longer revegetation time (Groups 2 and 3), but gently increased for the one with a shorter restoration time (Group 1). In Groups 2 and 3, soil loss rate decreased when plot area enlarged. In Group 1, it decreased before a plot area threshold of $18 \mathrm{~m}^{2}$ was exceeded. However, the increase occurred when plot area crossed the threshold value. In conclusion, the high vegetation cover alone did not lead to reduction in the runoff coefficient during the early stages of revegetation. When evaluating hydrological and soil erosion responses to revegetation, the soil compaction processes should be considered. Additionally, the effect of scale on runoff and soil erosion was found to be dependent on restoration extent, and thus on restoration time.
\end{abstract}

(C) 2011 Elsevier B.V. All rights reserved.

\section{Introduction}

Soil erosion is a critical environmental hazard in terrestrial ecosystems when it surpasses a tolerable rate (Zuazo and Pleguezuelo, 2008). The Loess Plateau in north-west China has suffered from terrible soil erosion in recent decades (Zhang et al., 1998; Shi and Shao, 2000) due to intensive human disturbance and the presence of thick erodible soil (Shi and Shao, 2000; He et al., 2004). The average area with soil loss over $50 \mathrm{tha}^{-1} \mathrm{yr}^{-1}$ was up to $42 \%$ of the total area of the Loess Plateau during 1955-1989 (Wang and Jiao, 2002). In the same period, the recorded average soil loss in the Huangfuchuan watershed of the Loess Plateau was $157 \mathrm{tha}^{-1} \mathrm{yr}^{-1}$ (Ran et al., 2003). The soil loss significantly exceeded the tolerance

\footnotetext{
* Corresponding author. Tel./fax: +8610 62923557.

E-mail address: bfu@rcees.ac.cn (B. Fu).
}

rate $\left(10 \mathrm{tha}^{-1} \mathrm{yr}^{-1}\right)$ for this region (Ministry of Water Resources of PR China, 2008). Furthermore, the Loess Plateau is the main source area for sediment discharging into the Yellow River (Ren and Shi, 1986; Shi and Shao, 2000; Xu, 2003). Between 1919 and 1989, approximately $90 \%$ of the sediment in the Yellow River (1.6 billion tons per year) came from the Loess Plateau (Xu, 2003; Xu and Yan, 2005). In-situ ecosystem degradation in the Loess Plateau (Zhang et al., 1998; Zheng, 2005) and elevation of the riverbed at the lower Yellow River (Shi and Shao, 2000) are the most serious consequences of the intensive soil erosion.

Abandonment of croplands for revegetation in sloping areas is one of the important management policies in the Loess Plateau (Jiao et al., 2007). In the 1980s, watershed eco-restoration projects targeted at soil erosion prevention and flood control were implemented in some watersheds. After 1998, the Chinese government implemented the Grain-for-Green project to reduce soil erosion across the country (Cao et al., 2009). As a part of this project, vast areas of cropland in mountainous areas were converted into forestland or grassland in 
the gully and hilly zones of the Loess Plateau (Li et al., 2009; Wang et al., 2010).

The revegetation resulted in an increase in vegetation cover (Xin et al., 2008), an improvement in soil nutrient levels (Zhou et al., 2008; Qiu et al., 2009) and in the recovery of soil physical properties (Li and Shao, 2006). These changes caused significant responses in hydrological function and soil erosion. Enhanced evapotranspiration (Zhang et al., 2001), soil hydraulic conductivity (Lichner et al., 2007), infiltration (Thompson et al., 2010) and improved soil resistance to erosion were also the consequences (Liu, 1997; Zhu et al., 2010), concurrently with the revegetation. In addition, the connectivity of runoff and sediment source areas was reduced (Molina et al., 2009). Thus, a significant reduction in runoff (Borg et al., 1988; Scott et al., 2000) and soil erosion (Marques et al., 2007) followed the revegetation. Paired catchment experiments are an ideal way to detect hydrological responses to revegetation. These involve the use of two catchments with similar slope, aspect, soils, area, climate and vegetation located in close proximity to each other. After a calibration period, one of the catchments is subjected to treatment in vegetation cover and the other remains as a control. The climatic variability can be accounted for in the following analysis. Therefore, the change in water yield can be attributed mainly to change in vegetation cover. The experiments in paired catchments in South Africa showed that afforestation reduced annual stream flow by $3.2 \%$ and low flow by $7.8 \%$ (Scott et al., 2000). With longer growth time, the percentage of reduction increased (Scott and Smith, 1997). In the Andean highlands of Ecuador, the comparative experiment undertaken by Buytaert et al. (2007) showed that afforestation reduced water yield by up to $50 \%$. Based on a review of 94 experiment catchments, Bosch and Hewlett (1982) concluded that increasing vegetation cover caused reduction in water yield. It has also been well illustrated that soil erosion prevention is an important function of vegetation cover (Nearing et al., 2005; Marques et al., 2007; Zuazo and Pleguezuelo, 2008). With respect to the Loess Plateau, many studies have focused on hydrological response and soil erosion change in relation to cropland abandonment for revegetation. Field experiments at the watershed scale in the Loess Plateau have showed that revegetation has resulted in a significant reduction in runoff (Huang et al., 2003; Zhang et al., 2007, 2010; Wang et al., 2009) and sediment yield (He et al., 2004; Zhou et al., 2006; Zhang et al., 2010). Applying the model developed by Zhang et al. (2001), it was concluded that forestation reduced $50 \%$ of the potential water yield by enhancing evapotranspiration in the Loess Plateau (Sun et al., 2006). Using the same model, Zhang et al. (2008) also illustrated that revegetation reduced stream flow in a sub-region of the Loess Plateau. The decrease in runoff (Wang et al., 2008) and sediment yield of revegetated land compared to cropland was also observed at the plot scale (Zheng, 2006; Zhou et al., 2006).

Most of the above studies compared hydrological variables and soil erosion of cropland or deforested land with that of revegetated land. Change in vegetation cover was the main factor considered and some inter-stage changes were ignored. The importance of sitespecific change in soil properties occurring with change in vegetation cover in controlling runoff generation and soil erosion over time has not been evaluated in detail. The change in soil properties on abandoned mountainous cropland with time is expected to be complex. It is no doubt interrelated with changes in vegetation cover and affected by previous intensive agricultural activities. The Loess Plateau is covered by thick and erodible loess (Shi and Shao, 2000; He et al., 2004). Additionally, it is a region with a high population density and intensive agricultural activities (He et al., 2004; Wang et al., 2006). Before abandonment of cropland, periodic tillage kept the surface soil layer loose. When croplands were abandoned and no longer tilled, the loose topsoil experienced a compaction process during the early restoration stage of several years to decades caused by natural forces such as rainfall hitting and human activities such as grazing (Li et al., 2004). In the long-term (up to 150 years) the surface soil layer may loosen again with grazing be banned (Li and Shao, 2006). Several field measurements in the Loess Plateau recorded a lower soil bulk density (Lian et al., 2006; Liu and Shao, 2008; Yu et al., 2009) and a higher porosity (Xing et al., 2010) in cropland, than that in abandoned cropland with low vegetation cover, forestland or grassland. The simulated rainfall experiment of Li et al. (2004) showed that infiltration rates in land abandoned for 1 to 2 years was higher than that abandoned for 5 to 7 years. These results confirmed the existence of the compaction process after cropland abandonment during the early stage of revegetation in the Loess Plateau. A similar process was also reported in the Andes (Molina et al., 2007): because of lower soil infiltration rates, more runoff was generated on abandoned land compared with arable land. Therefore, a simple reduction trend may not completely express the hydrological and soil erosion variation caused by revegetation in the Loess Plateau. There may be some changes in hydrological and soil erosion responses that were overlooked in previous studies.

Hydrological responses, represented in particular by the runoff coefficient and sediment yield are also scale dependent (Cammeraat, 2004). There were more opportunities for water re-infiltration in down slope areas (Kirkby et al., 2002; Gomi et al., 2008) and sediment to be trapped and deposited due to impedance of the vegetation buffer and topographical ponds (Kirkby, 2001; Kirkby et al., 2002; Blanco-Canqui et al., 2004; Rey, 2004; Fryirs et al., 2007). Consequently, runoff coefficients and sediment yield were found to decrease with an increasing plot area (Cammeraat, 2004; Cerdan et al., 2004; Yair and Raz-Yassif, 2004; de Vente and Poesen, 2005; Descroix et al., 2008; Moreno-de las Heras et al., 2010). However, Wilcox et al. (2003) illustrated that the disturbance could alter the effect of scale on runoff and erosion because of the modification of vegetation patterns. With scale expansion, the degree of runoff decrease may diminish, and soil erosion may even be enhanced. Moreno-de las Heras et al. (2010) confirmed that the effect of scale on runoff and erosion depended on the extent of degradation. The abandonment of cropland for revegetation is a method for restoring degraded land. The extent of degradation has been found to be more severe with shorter revegetation periods. Therefore, the scale of effect on runoff and sediment yield may be different for abandoned cropland with different restoration times in the Loess Plateau.

In this study, we first focused on the issue of hydrological response and soil erosion change during revegetation, which led to changes in vegetation cover and soil properties. Due to the soil compaction process, it was hypothesized that the response in runoff generation and erosion at the early stage of revegetation, after cropland abandonment in the Loess Plateau, was different from that in the long-term. Runoff may not always decrease during early stages of revegetation with increasing vegetation cover and concurrent changes in soil properties. Soil erosion may also not continue to decline. Therefore, the first objective of this study was to document the unique hydrological response and soil erosion change during the early stage of revegetation that was not clearly captured in previous studies at the plot scale in the Loess Plateau.

Secondly, it was hypothesized that the effect of scale on runoff and sediment yield did not always follow the usually reported declinewith-increasing-area rule. The scale effect may be dependent on restoration extent, which closely related to revegetation time. Correspondingly, the second objective of this study was to detect the effect of scale enlargement on runoff and soil erosion at the plot scale while considering the extent of land restoration.

To untangle these issues, a comparative plot experiment on runoff generation, soil erosion and the effect of scale was undertaken. Three typical revegetated plot groups of two different restoration times were established. These plot groups were: (1) covered by sparse young trees and annual grass and abandoned for 8 years; (2) dominated by dense native shrubs with an arborous layer of artificial old trees and abandoned for 25 years; and (3) covered by dense tussock and grass and revegetated for 25 years. 


\section{Materials and methods}

\subsection{Study area}

The study was carried out in the Yangjuangou catchment $\left(36^{\circ} 42^{\prime} \mathrm{N}\right.$, $109^{\circ} 31^{\prime} \mathrm{E}$ ), which is located in the centre of the Loess Plateau near Yan An City in Shaanxi Province, China (Fig. 1). The catchment has a total area of $2.02 \mathrm{~km}^{2}$ and elevation ranging from 1050 to $1298 \mathrm{~m}$. It is a typical gully and hilly area with a gully density of $2.74 \mathrm{~km} \mathrm{~km}^{-2}$ and slope gradients ranging from $10^{\circ}$ to $30^{\circ}$ (Li et al., 2003). The area has a semiarid continental climate with an average annual rainfall of $535 \mathrm{~mm}$. Rainfall events occur mainly between June and September with large inter-annual variations. Soil in the study area was derived from loess with a maximum depth of approximately $200 \mathrm{~m}$. The soil type is Calcaric Cambisol which is characterized by a uniform texture and weak structure, and is vulnerable to water erosion (Li et al., 2003). Surveys of sediment in the reservoir at the outlet of the catchment showed that the mean soil erosion rates were $90.42 \mathrm{t} \mathrm{ha}^{-1} \mathrm{yr}^{-1}$ between 1980 and 1990 and $62.73 \mathrm{tha}^{-1} \mathrm{yr}^{-1}$ during 1992-1996 (Li et al., 2003). Measured by the ${ }^{137} \mathrm{Cs}$ tracing technique, the average erosion rate of the Yangjuangou catchment was $89.79 \mathrm{t} \mathrm{ha}^{-1} \mathrm{yr}^{-1}$ during 1991-1996 (Li et al., 1997) and $36.41 \mathrm{t} \mathrm{ha}^{-1} \mathrm{yr}^{-1}$ in 2006 (Wang et al., 2009).

Reforestation began in the 1980 s on infertile and steep cultivated lands with low crop yields. As result of Grain-for-Green project launched in 1998, most of the cultivated lands on steep slopes were abandoned for natural or artificial revegetation. Grasslands and forestlands now dominate the hillslopes. Shrubs are now thriving at the bottom of north-facing slopes. The main forest species in the Yangjuangou catchment is acacia (Robinia pseudoacacia), which was planted in the 1980s and after 1999. The dominant grass species are
Artemisia sacrorum, Stipa bungeana and Artemisia scoparia. The main shrub species are Prunus armeniaca and Hippophae rhamnoide. A mosaic of patchy land cover, comprised of areas with different revegetation time and soil properties, is the typical landscape pattern in the Yangjuangou catchment as a result of human disturbances as well as climatic and topographical conditions.

\subsection{Experiment setup and data collection}

\subsubsection{Runoff plot descriptions}

The typical revegetation procedure in the Loess Plateau involved the planting of trees first and then allowing natural succession to take place. After abandoning cropland for revegetation, three typical land cover types were established: (1) abandoned cropland covered by sparse trees and annual grass; (2) native shrubs with an arborous layer of sparsely artificial wood; and (3) dense grass. Three plot groups were set up accordingly (Fig. 2). Group 1 was at the initial stage of revegetation and had been abandoned for 8 years. Groups 2 and 3 had been revegetated for 25 years. Each plot group included three closed plots with a fixed width of $2 \mathrm{~m}$ and lengths of 5, 9 and $13 \mathrm{~m}$ respectively. The vegetation of Group 1 was sparse apricot (Armeniaca vulgaris) planted in rows at interval distances of 2.5 or $5 \mathrm{~m}$ and was not managed after planting in 2000. Patchy biological crusts covered most of the soil surface of plots in Group 1. Dense native shrubs with an arborous layer of sparse artificial acacia covered plots of Group 2. Plots of Group 3 were dominated by dense tussock (A. scoparia) and beard grass (Andropogon L.), under natural succession with imbedded bare areas. The slope gradients of all plots were approximately $22^{\circ}$. Two numbers were used to define the group and length of each plot. For example, plots 11, 12 and 13 indicated that

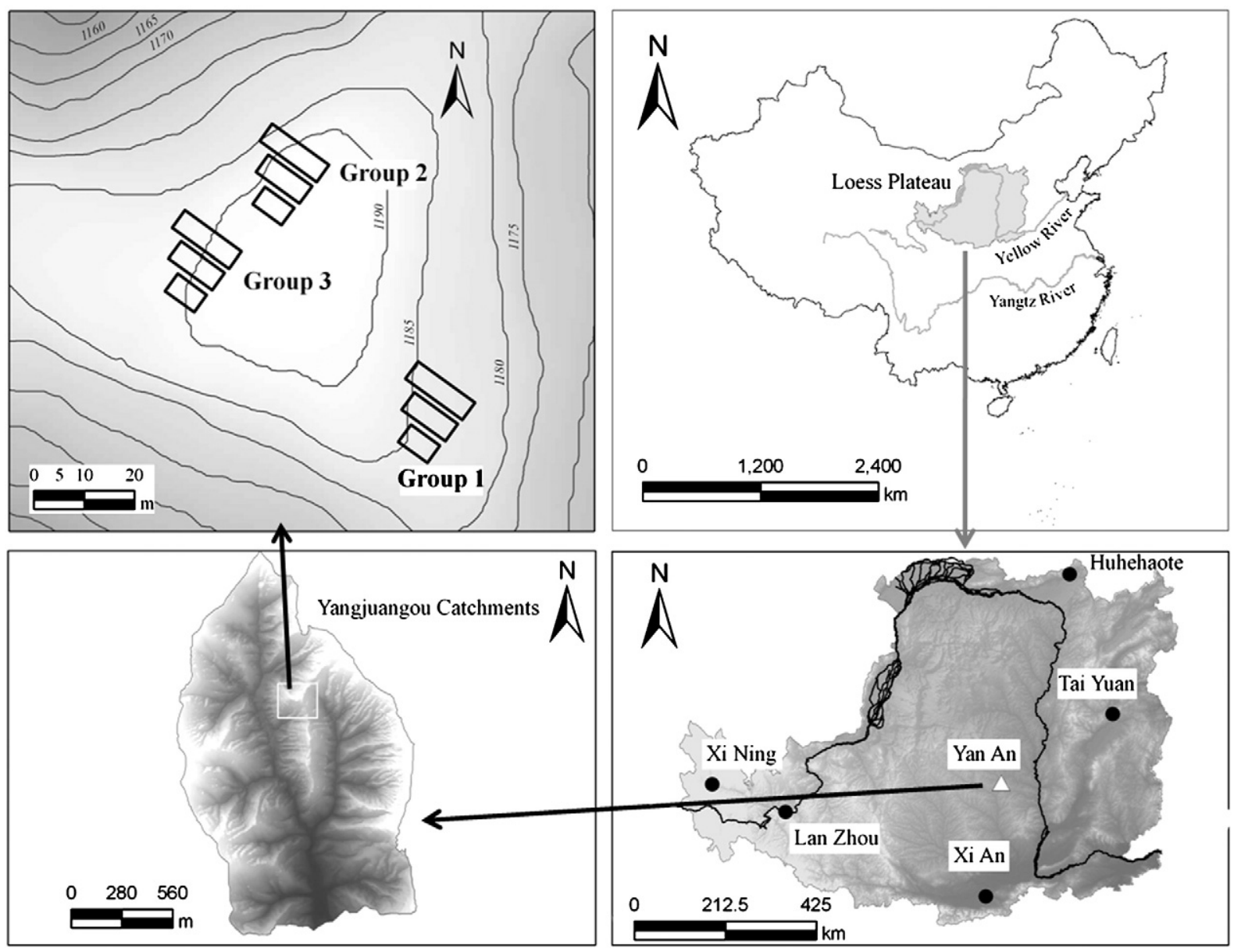

Fig. 1. Location of the study site. 

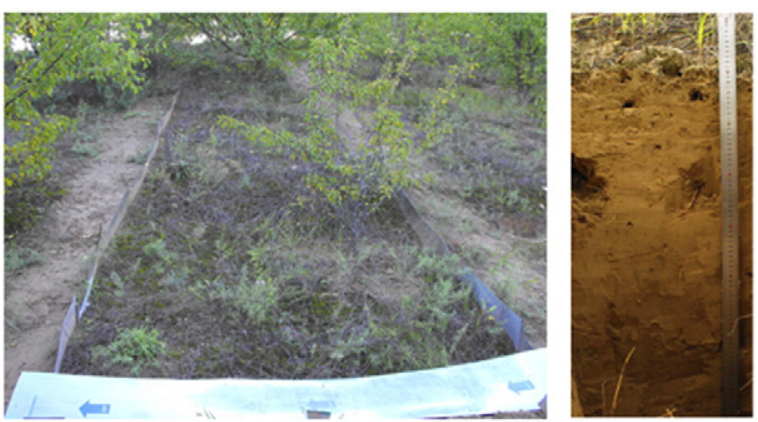

Group 1
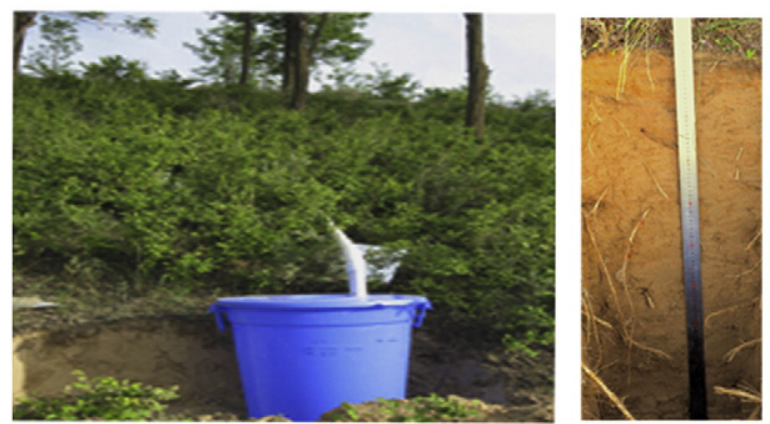

Group 2
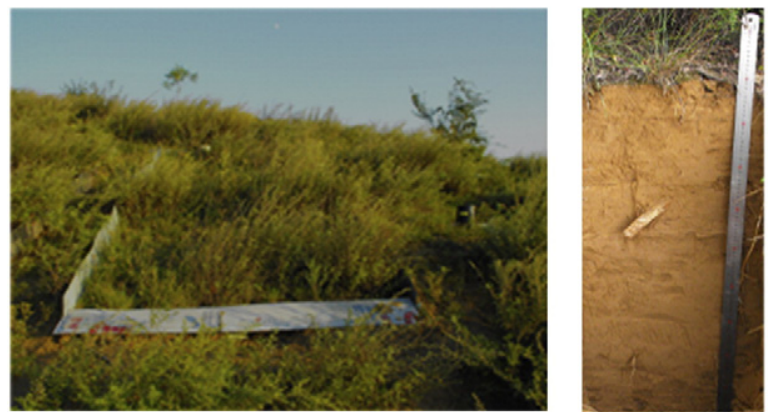

Group 3

Fig. 2. Pictures of runoff plots and soil profiles of plot groups.

these plots belonged to Group 1 and their lengths were 5, 9 and $13 \mathrm{~m}$, respectively.

\subsubsection{Soil property measurement and land cover mapping}

At the beginning of the monitoring program, 27 samples of topsoil $(0-10 \mathrm{~cm})$ were collected from each plot group. Total Kjeldhal nitrogen $(T N)$, total carbon $(T C)$, total phosphorous $(T P)$, soil organic carbon (SOC), electrical conductivity $(E C)$ and $p H$ were tested using standard soil testing methods (Liu et al., 1996). Soil texture was analyzed using a Mastersizer 2000 particle analyser (Malvern Instruments Ltd., Worcestershire, UK). Bulk density ( $B D)$ distributions for soil profiles of $65 \mathrm{~cm}$ in depth were measured at $5 \mathrm{~cm}$ interval for each plot group. Steady infiltration rate $\left(K_{0}\right)$ was obtained from in-situ measurements using a double ring infiltrometer. For each group, it was determined from the average value of five positions.

The ground cover for each plot was mapped using a $50 \times 50 \mathrm{~cm}$ subplot mesh and a digital camera (Finepix S1000, Fujifilm). A $50 \times 50 \mathrm{~cm}$ PVC pane with $5 \times 5 \mathrm{~cm}$ sub-mesh was applied for mapping ground vegetation cover in Group 1 . The location of the submesh was defined by row and column in a coordinate system where the origin was set at the bottom left of the plots. If more than half of a sub-mesh was covered by vegetation, it was coded as vegetation-covered. Otherwise, a further measurement of biological crust cover was conducted following the same procedure as ground vegetation cover. These records were transferred to digital vegetation cover maps using ArcMap (ESRI Inc., California, USA). In Groups 2 and 3 , each $50 \times 50 \mathrm{~cm}$ subplot was photographed at a height of $2 \mathrm{~m}$ above the ground. These pictures were merged together using ERDAS 9.1 (ERDAS Inc., Georgia, USA) after coordinate rectification and then transferred to a vegetation cover map in ArcMap.

To measure the canopy cover of the three plot groups, the total area of the vertical projection of the outermost perimeter of the canopy located in each plot was measured. Within the projection area, canopy cover was judged as $100 \%$. Canopy cover, ground vegetation cover and biological crust cover were calculated for each plot and each group.

\subsubsection{Runoff, erosion and soil moisture measurement}

Rainfall depth was measured to an accuracy of $0.2 \mathrm{~mm}$ using a tipping bucket rain gauge that was connected to a data logger. Rainfall erosivity index $\left(E I_{30}\right)$ was calculated following Wischmeier and Smith (1978). The runoff mixed with the sediment discharged from each plot was collected after each rainfall event and the volume measured. After settling for $24 \mathrm{~h}$, sediment was separated from water, dried in an oven at a temperature of $105^{\circ} \mathrm{C}$ for $8 \mathrm{~h}$ and weighed. This monitoring program was undertaken from 28 June to 29 August in 2008 and from 9 May to 28 August in 2009.

Soil volumetric moisture content (SVM) is the fraction of the total volume of soil that is occupied by water. It was measured using a profile probe (PR2, Delta-T Devices Ltd., Cambridgeshire, UK) at depths of $10,20,30$ and $40 \mathrm{~cm}$ from 20 May to 26 August in 2009. The results were calibrated against gravimetric measurements. At each depth, SVM was calculated as the average values of nine monitoring points in each plot group. The conventional measurements were made at an interval of four days. There were additional measurements before and after each rainfall event to capture the significant variation of soil moisture. In total, twenty-nine SVM measurements were obtained at each depth.

The profile distributions of gravimetric water content (GWC) were determined for each plot group after a large rainfall event on 22 July 2008. There were seven profiles for each plot group. Soil samples were collected for each profile at $20-100 \mathrm{~cm}$ below the soil surface at an interval of $20 \mathrm{~cm}$ and weighed immediately. GWC was calculated after samples were dried for $8 \mathrm{~h}$ in an oven at $105^{\circ} \mathrm{C}$ and weighed.

Wetting front depth is an effective indicator of vertical water movement in soil. Measurements of wetting front depth in the three plot groups were implemented on 25 August 2009. One profile with a width of $100 \mathrm{~cm}$ and a depth of $100 \mathrm{~cm}$ within each plot group was investigated using a steel ruler.

\subsection{Data analysis}

The runoff coefficient $(R C)$ was computed as the ratio of runoff depth to rainfall depth in each plot. Soil loss rates were defined as

Table 1

Soil properties and land cover of three runoff plot groups.

\begin{tabular}{lccc}
\hline & Group 1 & Group 2 & Group 3 \\
\hline Sand (\%) & 72.96 & 71.25 & 71.10 \\
Silt (\%) & 22.83 & 24.40 & 24.39 \\
Clay (\%) & 4.21 & 4.36 & 4.5 \\
$B D^{\mathrm{a}}\left(\mathrm{g} \mathrm{cm}^{-3}\right)$ & 1.04 & 1.30 & 1.17 \\
$K_{0}{ }^{\mathrm{b}}\left(\mathrm{mm} \mathrm{min}^{-1}\right)$ & 3.95 & 2.85 & 2.29 \\
Ground cover $(\%)_{\text {Canopy cover }(\%)}^{5.2}$ & 41.4 & 80.7 & 81.5 \\
Biological crust cover (\%) & 54.1 & 27.9 & 0.0 \\
\hline
\end{tabular}

a $B D$ : bulk density.

b $K_{0}$ : steady infiltration rate. 


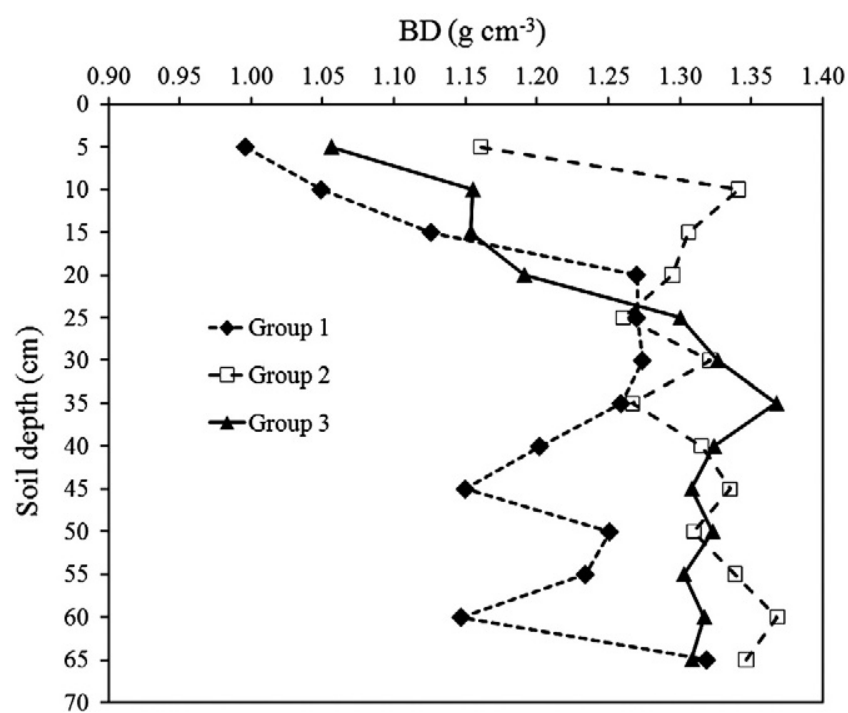

Fig. 3. Variation of soil bulk density $(B D)$ with depth in the three plot groups sampling at an interval depth of $5 \mathrm{~cm}$.

sediment exported per square meter. Statistical analysis was conducted using SPSS 13.0 (SPSS Inc., Illinois, USA).

\section{Results}

\subsection{Land cover and soil properties}

Vegetation coverage varied among plot groups (Table 1). The ground vegetation cover of plots in Group 1 ranged between $4.7 \%$ and $6 \%$. The corresponding total vegetation cover, which included canopy cover and ground cover, varied between $23 \%$ and $56 \%$. The plots in Groups 2 and 3 had significantly higher ground vegetation cover (>69\%) compared to Group 1. Biological crust cover of plots in Group 1 ranges from $44 \%$ to $74 \%$, which was higher than that of Groups 2 and 3 (varying between 2\% and 17\%).

The texture of topsoil in the three plot groups was sandy loam (Soil Survey Division Staff, 1993) (Table 1). Group 1 had the lowest $B D$ values in the surface layer $(0-25 \mathrm{~cm})$ (Fig. 3). In Groups 2 and 3, BD values were similar below a depth of $25 \mathrm{~cm}$, and both were significantly higher than in Group 1 (Fig. 3). $K_{0}$ of Group 1 ( $3.95 \mathrm{~mm} \mathrm{~min}^{-1}$ ) was higher than that of Group 2 (2.85 $\left.\mathrm{mm} \mathrm{min}^{-1}\right)$ and Group $3\left(2.29 \mathrm{~mm} \mathrm{~min}^{-1}\right)$ due to the loose soil structure.

$p H(p<0.001)$, lower TN $(p<0.0001), T C(p<0.0001)$ and SOC $(p<0.0001)$ values from Group 1 were statistically higher than those of Groups 2 and 3 (Table 2). The values of TP $(p<0.001)$ and EC $(p<0.0001)$ of Group 1 were significantly lower than that of Group 2. All indicators except for $p H$ were higher for Group 2 than for Group 3 with $p<0.0001$. In general, the level of soil nutrient content and SOC of the three plot groups was in the following order: Group

Table 2

Soil properties of runoff plots.

\begin{tabular}{llllllll}
\hline & Plot & \multicolumn{1}{l}{$\begin{array}{l}\text { TN } \\
(\%)\end{array}$} & $\begin{array}{l}\text { TC } \\
(\%)\end{array}$ & $\begin{array}{l}\text { SOC } \\
\left(\mathrm{g} \mathrm{kg}^{-1}\right)\end{array}$ & $\begin{array}{l}\text { TP } \\
\left(\mathrm{g} \mathrm{kg}^{-1}\right)\end{array}$ & $p H$ & $\begin{array}{l}E C \\
\left(\mu \mathrm{cm}^{-1}\right)\end{array}$ \\
\hline Group 1 & Plot 11 & 0.06 & 1.90 & 8.12 & 0.61 & 8.45 & 127.7 \\
& Plot 12 & 0.06 & 1.91 & 5.26 & 0.61 & 8.43 & 131.9 \\
& Plot 13 & 0.07 & 1.91 & 8.86 & 0.62 & 8.37 & 139.5 \\
Group 2 & Plot 21 & 0.12 & 2.52 & 16.97 & 0.64 & 8.27 & 158.1 \\
& Plot 22 & 0.12 & 2.52 & 15.79 & 0.64 & 8.30 & 147.6 \\
& Plot 23 & 0.12 & 2.56 & 16.56 & 0.66 & 8.26 & 155.7 \\
Group 3 & Plot 31 & 0.09 & 2.14 & 18.03 & 0.63 & 8.32 & 148.7 \\
& Plot 32 & 0.10 & 2.21 & 21.89 & 0.61 & 8.33 & 130.8 \\
& Plot 33 & 0.10 & 2.31 & 20.22 & 0.62 & 8.30 & 137.5 \\
\hline
\end{tabular}

Table 3

Distribution (\%) of mean rainfall intensity (MRI) during the monitoring period.

\begin{tabular}{lllllr}
\hline $\begin{array}{l}\text { MRI } \\
\left(\mathrm{mm} \mathrm{min}^{-1}\right)\end{array}$ & $\begin{array}{l}\text { Proportion } \\
\text { of total } \\
\text { events (\%) }\end{array}$ & $\begin{array}{l}\text { Cumulative } \\
(\%)\end{array}$ & $\begin{array}{l}\text { Proportion of } \\
\text { total rainfall } \\
\text { depth (\%) }\end{array}$ & $\begin{array}{l}\text { No. of } \\
\text { events }\end{array}$ & $\begin{array}{l}\text { Rainfall } \\
\text { depth } \\
(\mathrm{mm})\end{array}$ \\
\hline$<0.1$ & 76.7 & 76.7 & 70.7 & 33 & 385.2 \\
$0.1-0.2$ & 14.0 & 90.7 & 20.7 & 6 & 112.6 \\
$0.2-0.3$ & 2.3 & 93.0 & 2.9 & 1 & 15.8 \\
$0.3-0.5$ & 2.3 & 95.3 & 1.1 & 1 & 6.2 \\
$0.5-1.0$ & 4.7 & 100.0 & 4.6 & 2 & 25.2 \\
\hline
\end{tabular}

Table 4

Number of rainfall event produced runoff (FR) and sediment (NSY) of each plot.

\begin{tabular}{|c|c|c|c|c|c|c|c|c|c|}
\hline & \multicolumn{3}{|l|}{ Group 1} & \multicolumn{3}{|c|}{ Group 2} & \multicolumn{3}{|l|}{ Group 3} \\
\hline & Plot 11 & Plot 12 & Plot 13 & Plot 21 & Plot 22 & Plot 23 & Plot 31 & Plot 32 & Plot 33 \\
\hline$F R$ & 9 & 9 & 10 & 12 & 11 & 11 & 12 & 12 & 12 \\
\hline NSY & 5 & 5 & 6 & 6 & 6 & 6 & 6 & 6 & 6 \\
\hline
\end{tabular}

$2>$ Group $3>$ Group 1 . The elevated soil nutrient content and SOC of Groups 2 and 3 did not result in a higher steady infiltration rate.

\subsection{Rainfall regimes and threshold values}

Forty-three rainfall events occurred during observation periods in 2008 and 2009 (Table 3). The largest depth of rainfall in a single event reached $72.2 \mathrm{~mm}$ with a mean intensity of $0.029 \mathrm{~mm} \mathrm{~min}^{-1}(21-22$ August 2009). The minimum rainfall depth causing runoff generation was $6.2 \mathrm{~mm}$ with a mean intensity of $0.469 \mathrm{~mm} \mathrm{~min}^{-1}$ (24 August 2009). Intense storm is one of the main contributors to soil erosion in the Loess Plateau (Jiao et al., 1999). However, it was observed occasionally during the monitoring period (Table 3 ).

Table 4 lists runoff frequency $(F R)$ and the number of rainfall events that produced sediment (NSY). Both FR and NSY of Group 1 were slightly less than those of Groups 2 and 3. Approximately half of the rainfall events resulting in runoff generation produced sediment.

The rainfall threshold for runoff generation is the rainfall depth at which the probability of no runoff becomes negligible. It is a critical indicator of hydrological response and is calculated by plotting event runoff volume against event rainfall depth (Descheemaeker et al., 2006). Linear regression equations representing the relationship between runoff and rainfall were established using the least squares method for each plot. A typical rainfall-runoff relationship applied to determine rainfall

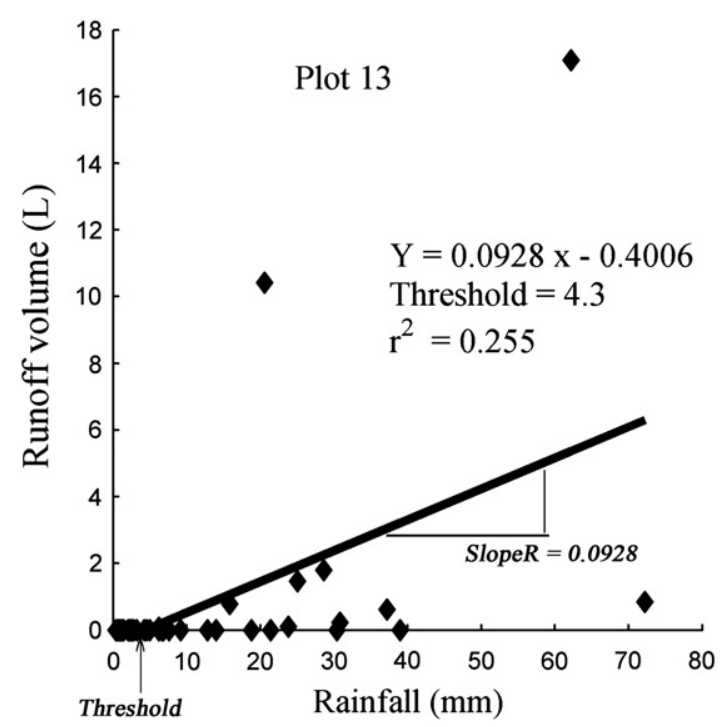

Fig. 4. Illustration of the determination of rainfall threshold and slope of rainfall-runoff curve (SlopeR). 
Table 5

Rainfall threshold and slope of the rainfall-runoff curve (slopeR) for each plot with coefficient of determination $\left(r^{2}\right)$, significance level $(p)$ and number of observations $(n)$.

\begin{tabular}{lllllll}
\hline & Plot & Threshold $(\mathrm{mm})$ & slopeR & $r^{2}$ & $p$ & $n$ \\
\hline Group 1 & Plot 11 & 2.4 & 0.019 & 0.318 & 0.000 & 43 \\
& Plot 12 & 3.7 & 0.046 & 0.297 & 0.000 & 43 \\
& Plot 13 & 4.3 & 0.093 & 0.255 & 0.001 & 43 \\
Group 2 & Plot 21 & 4.5 & 0.128 & 0.390 & 0.000 & 43 \\
& Plot 22 & 3.4 & 0.165 & 0.395 & 0.000 & 43 \\
& Plot 23 & 4.5 & 0.119 & 0.292 & 0.000 & 43 \\
Group 3 & Plot 31 & 3.2 & 0.099 & 0.230 & 0.001 & 43 \\
& Plot 32 & 3.8 & 0.166 & 0.264 & 0.000 & 43 \\
& Plot 33 & 3.7 & 0.182 & 0.239 & 0.001 & 43 \\
\hline
\end{tabular}

threshold and slope of a rainfall-runoff curve is illustrated in Fig. 4. The rainfall threshold, regression line slope (slopeR), determination coefficient of regression equations $\left(r^{2}\right)$, significance level $(p)$ and number of observed rainfall events $(n)$ for each plot are listed in Table 5.

Rainfall threshold values for all groups range between 2.4 and $4.5 \mathrm{~mm}$ (Table 5). The values were slightly lower for Group 1 compared to those of Groups 2 and 3. However, SlopeR values were higher for Groups 2 and 3 than for Group 1. This result implies that the efficiency of runoff generation in Groups 2 and 3 was greater than that in Group 1 after the rainfall threshold was exceeded.

\subsection{Soil moisture}

As shown in Fig. 5, little rainfall occurred between 27 May to 14 July and from 22 July to 16 August. During these periods, SVM values continuously declined. At depths of 10, 20 and $40 \mathrm{~cm}$, SVM of Group 3 was the highest, followed by that of Groups 1 and 2 (Fig. 5). SVM of Group 2 was the lowest at a depth of $30 \mathrm{~cm}$, especially during the period with scarce rainfall before July 14 . During the entire monitoring period SVM of Group 1 was significantly lower $(p<0.001)$ than the other two groups at depths of 10, 20 and $40 \mathrm{~cm}$. Groups 1 and 2 had similar SVM values at a depth of $30 \mathrm{~cm}$ and both were lower than that of Group 3. The lower SVM of the soil surface layer in Group $1 \mathrm{im}-$ plies less runoff generation than in Group 2 and 3.

Stepwise regression was used to analyze GWC profile distributions after the intense rainfall event happened on 22 July 2009 (Fig. 6). The slope of regression equation between soil moisture and depth was smallest in Group 1 and greatest in Group 3 (Fig. 6). This indicates that the difference in GWC along the soil profile was smaller in Group 1 than in Groups 2 and 3. Wetting front depth in Group 1 measured on 25 August, 2009 was over $100 \mathrm{~cm}$ and greater than that of Group 2 (about $85 \mathrm{~cm}$ ) and Group 3 (nearly $100 \mathrm{~cm}$ ). The comparison of GWC profile distributions and wetting front depths reveals that water traveled vertically easier in Group 1 than in Groups 2 and 3. This partly accounts for the relatively low runoff coefficient in Group 1, as illustrate in the next section.

\subsection{Runoff and soil erosion}

During the two monitoring periods in 2008 and 2009, runoff volume of each rainfall event was measured and runoff coefficients were calculated for all plots. Although vegetation cover, particularly ground cover, of Group 1 was significantly lower than that of Groups 2 and 3, runoff coefficients of Group 1 were unexpectedly low (Fig. 7). Group 2 had medium runoff coefficients while Group 3 had the highest (Fig. 7).

The average runoff coefficient of plots 11,12 and 13 in Group 1 was only $0.25 \%, 0.37 \%$ and $0.45 \%$, respectively. In Group 2 , the average runoff coefficient was $1.55 \%$ in plot $21,1.40 \%$ in plot 22 , and $0.56 \%$ in plot 23 . The values in Group 3 were $1.57 \%$ for plot $31,1.31 \%$ for plot 32 and $1.04 \%$ for plot 33 . Mean runoff coefficients of the three plot groups responded differently to changes in plot area (Fig. 8). They decreased with increasing plot area in Groups 2 and 3, but increased in Group 1.

Rainfall characteristics play an important role in runoff generation and soil erosion in the Loess Plateau (Fang et al., 2008). Runoff volume was significantly correlated to $\mathrm{EI}_{30}$ at all plots (Table 6). Nevertheless, the correlation between sediment amount and $E I_{30}$ was significant only for plots of Groups 1 and 3. A significant positive correlation between runoff coefficient and mean rainfall intensity (MRI) was found for all runoff plots (Table 7). No significant correlation was found between the runoff coefficient and rainfall duration. The correlation between total runoff and maximum rainfall within $10 \mathrm{~min}\left(I_{10}\right)$ was also not statistically significant. These results agree with those of Chaplot and Le Bissonnais (2003) and Cammeraat (2004). Except for plot 11, the correlation between the runoff coefficients and maximum rainfall within $30 \mathrm{~min}\left(I_{30}\right)$ was not significant.
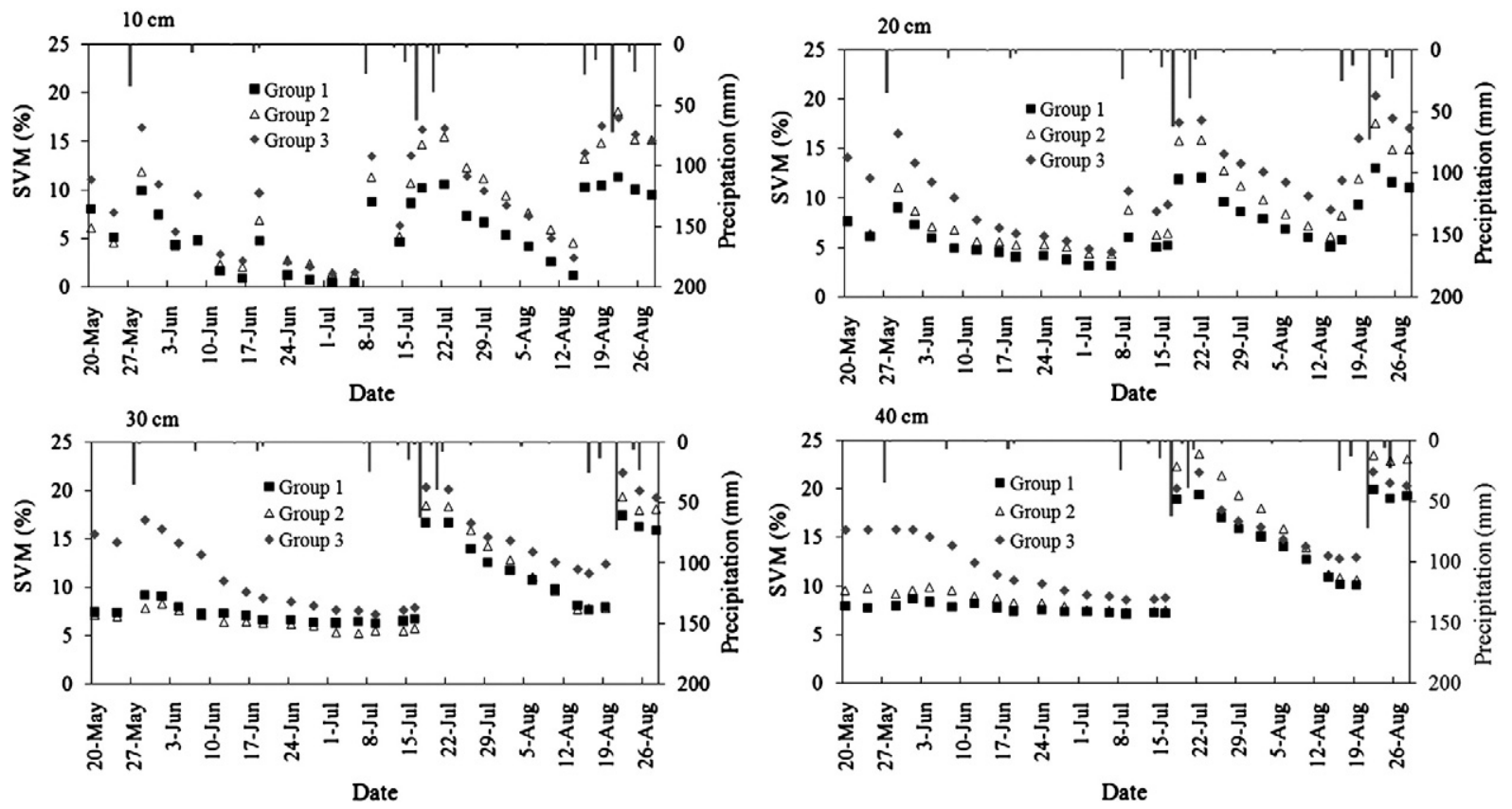

Fig. 5. Temporal variation of soil volumetric moisture (SVM) at four depths during monitored period in 2009. 

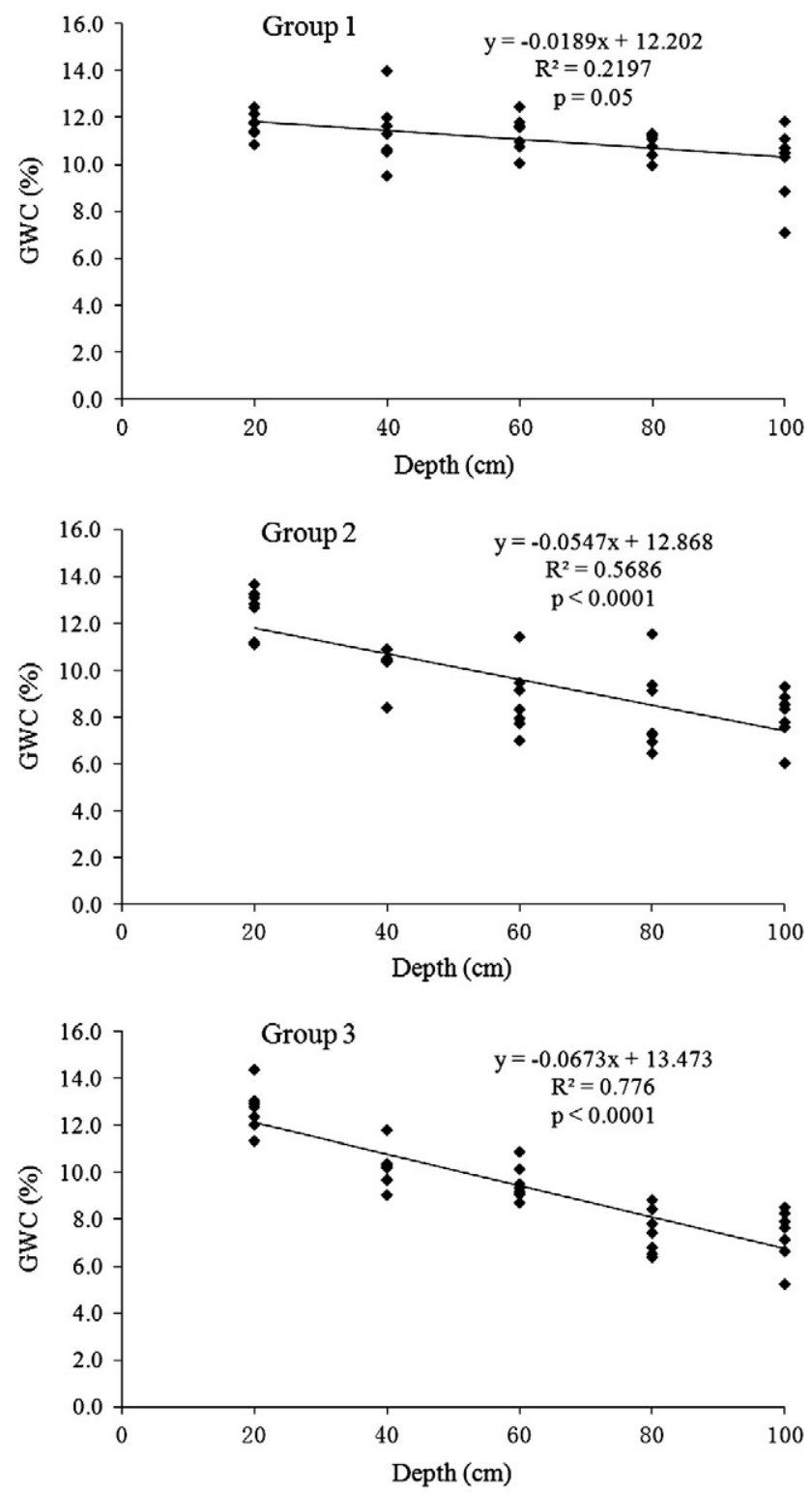

Fig. 6. Relationship of gravimetric water content (GWC) with depth after the intense rainfall event on 22 July 2009.

Although vegetation cover, particularly ground cover, of plots in Group 1 was evidently lower than that in Groups 2 and 3, the soil loss of Group 1 was not significantly higher (Fig. 8). This was partly due to the lower runoff coefficient and the formation of a protective biological crust in plots of Group 1. The soil loss rates of Groups 2 and 3 were higher than that of Group 1 when the plot area was 10 and $18 \mathrm{~m}^{2}$ (Fig. 8). However, it was highest in Group 1 when the plot area reached $26 \mathrm{~m}^{2}$. As plot area enlarged, soil loss rate changed differently among the three plot groups. It decreased with increasing plot area in Groups 2 and 3 (Fig. 8). In Group 1, it decreased when plot area increased from 10 to $18 \mathrm{~m}^{2}$ and then increased when plot area became greater than $18 \mathrm{~m}^{2}$ (Fig. 8 ).

\section{Discussion}

\subsection{Effects of land cover and soil properties on runoff}

Cropland abandonment for revegetation dramatically changed the vegetation cover and soil properties of the Loess Plateau. It resulted in an increase in vegetation cover (Xin et al., 2008) and changes in soil

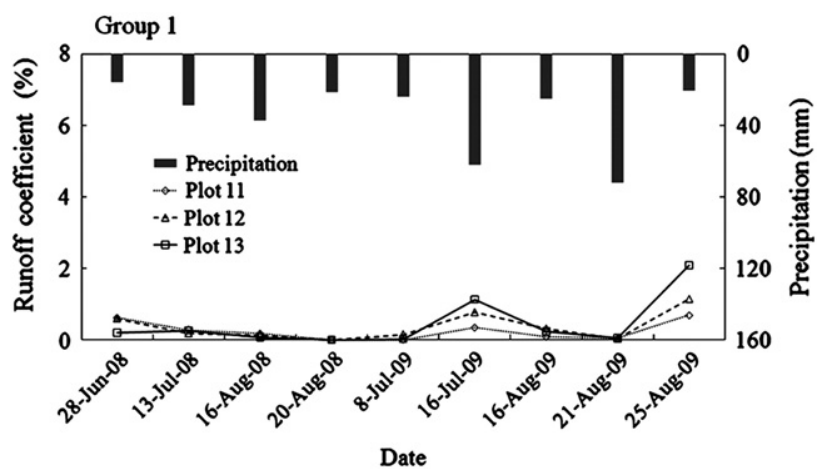

Group 2
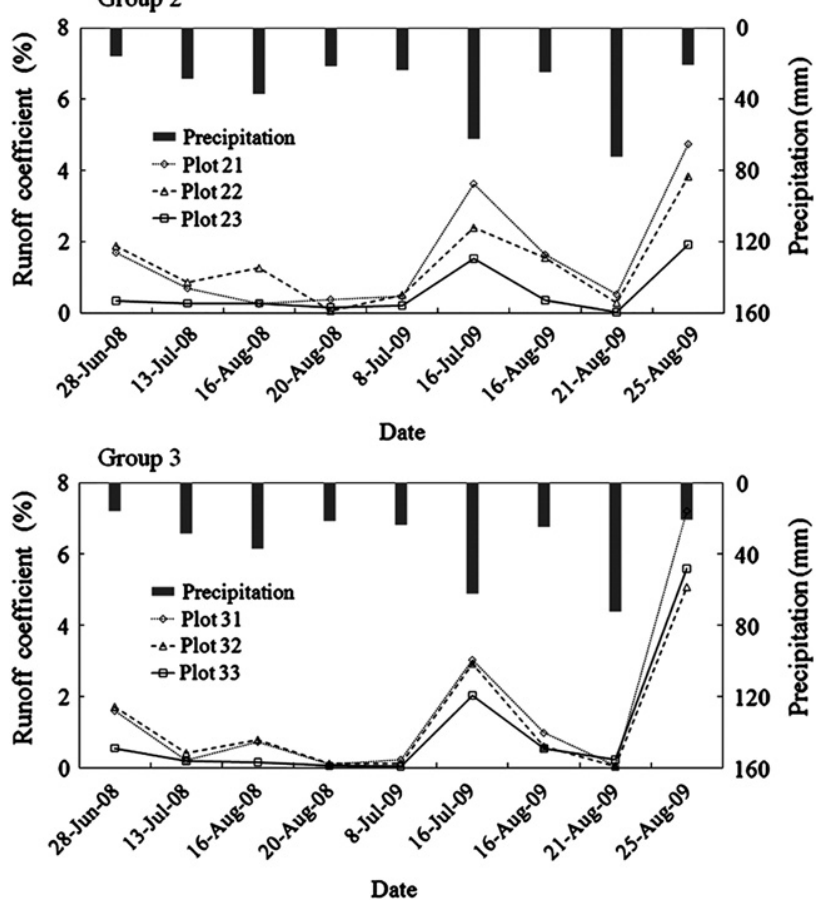

Fig. 7. Runoff coefficient of each rainfall event in different groups.

properties (Wen et al., 2005; Li and Shao, 2006) that were expected to impact hydrological behavior (Dunjó et al., 2004; Descheemaeker et al., 2006) and soil erosion (Zheng, 2006; Van Rompaey et al., 2007; Van Dessel et al., 2008). Vegetation cover was one of the key factors controlling rainfall threshold values for runoff generation. Vegetation interception, soil surface roughness and depression storages, soil seepage and evaporation are all factors affecting the rainfall threshold (Kirkby et al., 2002). With lower vegetation cover, particularly lower ground cover, rainfall threshold values of plots in Group 1 were smaller than those of Groups 2 and 3 (Table 5). From the lower $B D$ and higher $K_{0}$ of Group 1, it can be inferred that the difference in vegetation cover was one of the key factors affecting the rainfall threshold. Similar ground vegetation cover in Groups 2 and 3 and significant higher canopy cover in Group 2 than in Group 3 further confirmed that vegetation cover was the critical factor for the rainfall threshold.

Slopes of rainfall-runoff regression equations (Table 5) indicate that each rainfall unit produced more runoff in Groups 2 and 3 than in Group 1. This implies that the soil properties are important factors in runoff generation when rainfall depth crosses the threshold values. A lower $B D$ and $S V M$, higher $K_{0}$, deeper wetting front and smaller decline slope of GWC-depth curve were found in Group 1 compared to Groups 2 and 3. Plots of Group 1 also had a shorter restoration time than Groups 2 and 3. The profile distribution of $K_{0}, B D$ and GWC suggests that a compaction process occurred in the soil surface layer 

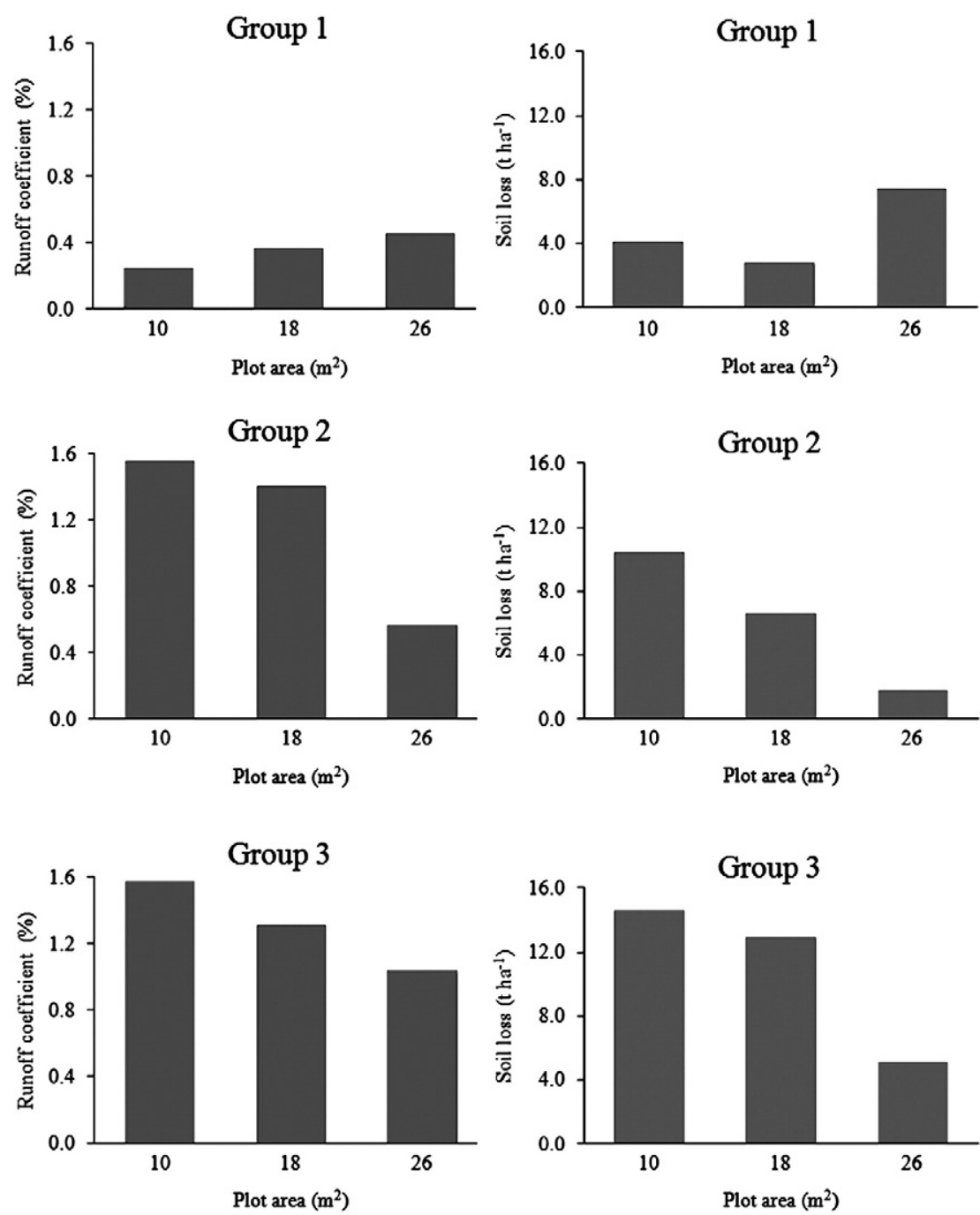

Fig. 8. Mean runoff coefficient and soil loss rate of each group at three plot scales.

during initial stages of revegetation. The compaction can significantly reduce soil infiltration rates (Li et al., 2004; Zhang et al., 2006) and saturated hydraulic conductivity (Zhang et al., 2006). It therefore is inferred that water infiltrated into deeper soil layers quicker and easier in Group 1 than in Groups 2 and 3. Studies revealed that the improvement of soil nutrient and organic carbon content can result in an increase in the infiltration rate and a decrease in runoff (Gilley and Risse, 2000; Descheemaeker et al., 2006). A lower steady infiltration rate, a higher runoff frequency and a greater runoff coefficient were unexpectedly found in Groups 2 and 3 compared to Group 1,

\section{Table 6}

Correlation coefficients between rainfall erosivity index $\left(E I_{30}\right)$ and runoff volume and sediment amount.

\begin{tabular}{llll}
\hline & Plot & Runoff volume & Sediment amount \\
\hline Group 1 & Plot 11 & $0.854^{\mathrm{a}}$ & $0.914^{\mathrm{a}}$ \\
& Plot 12 & $0.873^{\mathrm{a}}$ & $0.814^{\mathrm{a}}$ \\
& Plot 13 & $0.843^{\mathrm{a}}$ & $0.745^{\mathrm{b}}$ \\
Group 2 & Plot 21 & $0.863^{\mathrm{a}}$ & 0.384 \\
& Plot 22 & $0.902^{\mathrm{a}}$ & 0.443 \\
Group 3 & Plot 23 & $0.892^{\mathrm{a}}$ & 0.372 \\
& Plot 31 & $0.766^{\mathrm{b}}$ & $0.900^{\mathrm{a}}$ \\
& Plot 32 & $0.852^{\mathrm{a}}$ & $0.605^{\mathrm{b}}$ \\
& Plot 33 & $0.713^{\mathrm{b}}$ & $0.902^{\mathrm{a}}$ \\
\hline
\end{tabular}

a Correlation is significant at the 0.01 level (2-tailed).

b Correlation is significant at the 0.05 level (2-tailed). although soil nutrient and SOC were higher in the former two groups. These results highlight the important effect of soil compaction on hydrological changes after cropland was abandoned for revegetation in the Loess Plateau. Therefore, an increase in the runoff frequency and coefficients with restoration time in the early stages of revegetation can be expected. However, the runoff and soil erosion in revegetated areas were much lower than those in croplands in this region (Quine et al., 1999; Zheng, 2006; Wei et al., 2007). A comparison of the slopes of rainfall-runoff regression equations in Groups 2 and 3 also

Table 7

Correlation coefficients between runoff coefficient and rainfall characteristics.

\begin{tabular}{llllrl}
\hline Plot & Rainfall depth & Duration & MRI & \multicolumn{1}{l}{$I_{10}$} & \multicolumn{1}{l}{$I_{30}$} \\
\hline Plot 11 & -0.28 & -0.505 & $0.879^{\mathrm{a}}$ & 0.494 & $0.804^{\mathrm{a}}$ \\
Plot 12 & -0.132 & -0.456 & $0.848^{\mathrm{a}}$ & 0.179 & 0.585 \\
Plot 13 & -0.016 & -0.313 & $0.818^{\mathrm{a}}$ & -0.124 & 0.394 \\
Plot 21 & -0.002 & -0.328 & $0.760^{\mathrm{b}}$ & 0.015 & 0.470 \\
Plot 22 & -0.153 & -0.497 & $0.866^{\mathrm{a}}$ & 0.113 & 0.608 \\
Plot 23 & 0.037 & -0.363 & $0.734^{\mathrm{b}}$ & -0.096 & 0.401 \\
Plot 31 & -0.137 & -0.384 & $0.910^{\mathrm{a}}$ & 0.015 & 0.403 \\
Plot 32 & -0.09 & -0.415 & $0.889^{\mathrm{a}}$ & 0.102 & 0.502 \\
Plot 33 & -0.092 & -0.298 & $0.881^{\mathrm{a}}$ & -0.092 & 0.325 \\
\hline
\end{tabular}

MRI: mean rainfall intensity, $I_{10}$ : maximum rainfall within $10 \mathrm{~min}$; $I_{30}$ : maximum rainfall within $30 \mathrm{~min}$.

a Correlation is significant at the 0.01 level (2-tailed).

b Correlation is significant at the 0.05 level (2-tailed). 
demonstrates the importance of vegetation morphology and structure. Inferring from steady infiltration rates, it is expected that the plots in Group 3 have a higher runoff generation efficiency than Group 2. This is contrary to the results. Differences in vegetation morphology and structure impact runoff generation by changing the characteristics of the rainfall that reaches the soil surface (Llorens and Domingo, 2007; Xu et al., 2008).

However, previous studies on the soil properties of long-term revegetated land in the Loess Plateau showed different hydrological responses from those presented in this study. Long-term revegetation result in an increase in vegetation cover (Zhou et al., 2006; Xin et al., 2008) and the improvement of soil nutrient and SOC content in the Loess Plateau (Qiu et al., 2009). After a long-term revegetation (150 years) without harvesting, a decrease in bulk density and increase in saturated hydraulic conductivity in the top $20 \mathrm{~cm}$ of the soil surface layer was observed in this region (Li and Shao, 2006). These indicate a decrease in runoff generation in the long-term.

\subsection{Effects of land cover and soil properties on soil erosion}

It has been reported that the physical and chemical properties of soil in the Loess Plateau have been improved (Li and Shao, 2006; Qiu et al., 2009; Zhu et al., 2010) and that the soil erodibility has decreased (Liu, 1997; Zhu et al., 2010) with time after long-term abandonment of cropland for revegetation. In areas with a short revegetation time (as in Group 1), a low vegetation cover, a mosaic of biological crust and bare soil, low bulk density, high porosity and a high infiltration rates were found (Lian et al., 2006; Liu and Shao, 2008; Yu et al., 2009; Xing et al., 2010). The presence of a biological crust enhanced runoff generation and prevented soil erosion (Neave and Rayburg, 2007). Low bulk density and high porosity lead to high infiltration rates, which result in a relatively low runoff coefficient. After a longer period of revegetation (as experienced in Groups 2 and 3 in this study), the high vegetation cover, ground cover and litter cover in particular (Fig. 9), protected soil particles from raindrop detachment and impeded sediment transport. Soil compaction also reduces soil loss. Runoff generation was more efficient because of the low infiltration rate following soil compaction, in spite of improved contents of soil nutrient and organic carbon. As a result, soil loss was not significantly different among plot groups in this study.

If certain topographic thresholds such as slope gradient, slope length, and critical drainage area were crossed, gullying can be initiated with the presence of low vegetation cover (Valentin et al., 2005). Gully erosion has contributed to approximately $60-90 \%$ of the total sediment yield in the gully and hilly areas of the Loess Plateau (Li et al., 2003). High densities of antecedent gullys and channels at the bottom of hillslopes and in the valleys have been found in this region. Both hillslopes and valleys are the major sources of sediment (Shi and Shao, 2000; Li et al., 2003). As hillslopes are the main sources of runoff (Zheng et al., 1994; Chen and Cai, 2006), the higher runoff coefficients in plot groups with longer restoration times implies more supply of runoff. This enhanced gully erosion at both hillslope and catchments scales (Zheng et al., 1994; Chen and Cai, 2006).

\subsection{Effect of scale}

The results of this study confirm that extent of restoration altered the effect of scale on hydrological responses and soil erosion. Group 1 was in a more degraded state than Groups 2 and 3. The runoff coefficients of Groups 2 and 3 decreased with plot area. However, they gradually increased in Group 1. The soil loss rate decreased with increasing plot area in Groups 2 and 3. However, in Group 1 it decreased below an area threshold of $18 \mathrm{~m}^{2}$ and then increased with plot area when the plot area became greater. The connectivity of runoff sources influences this trend. With lower vegetation cover, a greater chance exists to promote the connectivity of runoff and sediment source areas (Mayor et al., 2008), as well as rill and even gully formation at larger scales (Wilcox et al., 2003). Thus, soil erosion may be enhanced (Valentin et al., 2005).

The Loess Plateau is covered with highly erodible soil (Li et al., 2003; Zheng, 2006). The abandoned croplands with a shorter restoration times experience more severe soil erosion when the scale considered was expanded to a whole hillslope and catchment compared to that with a longer restoration times. In addition to the enhanced connectivity of source areas and establishment of rills and gullies, water infiltrated more easily into deeper soil layers in abandoned croplands with a shorter restoration times due to loose soil surface layers. Unstable slopes and even landslides can thus be triggered more easily (Zhang and Liu, 2010). In summary, at the hillslope scale, the runoff coefficients and soil loss rates in abandoned croplands with a short restoration time increase with scale enlargement. For hillslopes with a longer restoration time, a decrease in runoff coefficients and soil loss can be expected when the scale enlarged.

\section{Conclusions}

The hydrological response, soil erosion potential and the effect of scale on runoff and soil erosion of abandoned croplands in sloping areas in the Loess Plateau of China were studied. Major hydrological variables (rainfall, runoff and soil moisture) and sediment production of three plot groups with different vegetation cover and restoration times were observed during the rainy seasons of 2008 and 2009. Higher runoff coefficients were found in plot groups with a restoration time of 25 years (Groups 2 and 3 ) than that with a restoration time of 8 years (Group 1). Runoff coefficients decreased with plot area in Groups 2 and 3 but increased in Group 1. Soil loss rates

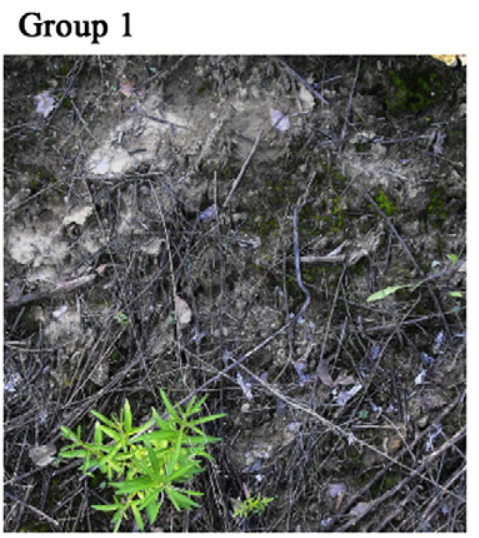

\section{Group 2}

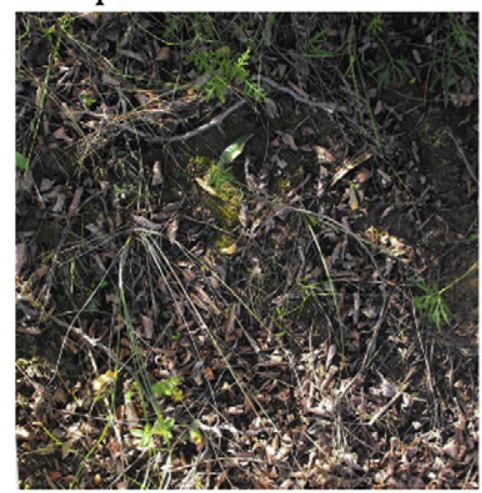

Group 3

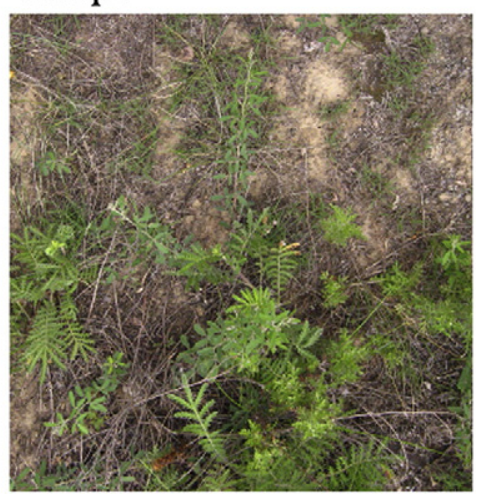

Fig. 9. Soil surface features of different runoff plot groups. 
decreased with the plot area in Groups 2 and 3, but increased over an area threshold in Group 1. Based on these results, the following three conclusions were drawn:

1) Due to soil compaction after the cropland abandonment, areas in early stages of revegetation experienced an increase in runoff generation at the plot scale, although vegetation cover, soil nutrient and organic carbon increased. Vegetation cover is the dominant factor affecting the rainfall threshold values. When the rainfall threshold values were exceeded, the soil hydrological properties were critical factors dominating runoff generation. Because of the occurrences of soil compaction, in the early stages of revegetation, it is incorrect to predict a reduction trend in runoff with time at the plot scale, although the vegetation cover dramatically increased.

2) At early stages of revegetation, the soil erosion did not significantly decline further although vegetation cover increased at the plot scale. The soil loss was low compared to that of cultivated land or deforested land in the Loess Plateau (Zheng, 2006). A significant difference in soil loss was not observed among plot groups with different revegetation times at the plot scale, although vegetation cover was significantly different. This indicates that the soil compaction should be taken into account in predicting hydrological responses and soil erosion potential after revegetation in the Loess Plateau.

3) The effect of scale on runoff and soil erosion was dependent on the extent of land restoration, and thus the restoration time. Runoff coefficients and soil loss rates decreased with plot area for plot groups with longer restoration times, but increased in plot groups with short restoration times.

\section{Acknowledgments}

The National Natural Science Foundation of China (Grant nos. 40930528 and 40871085), the Program of the State Forestry Administration of China (Grant no. 201004058) and the CAS/SAFEA International Partnership Program for Creative Research Teams of "Ecosystem Processes and Services" funded this work. We greatly acknowledge the Editor-in-Chief T. Oguchi and two reviewers for their detailed and constructive comments that have substantially improved the quality of this manuscript. We sincerely thank Sanjiv Rana and Halinka Lamparski for writing improvement. We thank Ren Zhenhai and Gao Caixia for their enthusiastic assistance with fieldwork.

\section{References}

Blanco-Canqui, H., Gantzer, C.J., Anderson, S.H., Alberts, E.E., Thompson, A.L., 2004 Grass barrier and vegetative filter strip effectiveness in reducing runoff, sediment, nitrogen, and phosphorus loss. Soil Science Society of America Journal 68, $1670-1678$.

Borg, H., Bell, R.W., Loh, I.C., 1988. Streamflow and stream salinity in a small water supply catchment in southwest Western Australia after reforestation. Journal of Hydrology $103,323-333$.

Bosch, J.M., Hewlett, J.D., 1982. A review of catchment experiments to determine the effect of vegetation changes on water yield and evapotranspiration. Journal of Hydrology 55, 3-23.

Buytaert, W., Iniguez, V., De Bievre, B., 2007. The effects of afforestation and cultivation on water yield in the Andean paramo. Forest Ecology and Management 251, 22-30.

Cammeraat, E.L.H., 2004. Scale dependent thresholds in hydrological and erosion response of a semi-arid catchment in southeast Spain. Agriculture, Ecosystems and Environment 104, 317-332.

Cao, S.X., Chen, L., Yu, X.X., 2009. Impact of China's Grain for Green Project on the landscape of vulnerable arid and semi-arid agricultural regions: a case study in northern Shaanxi Province. Journal of Applied Ecology 46, 536-543.

Cerdan, O., Le Bissonnais, Y., Govers, G., Lecomte, V., van Oost, K., Couturier, A., King, C. Dubreuil, N., 2004. Scale effect on runoff from experimental plots to catchments in agricultural areas in Normandy. Journal of Hydrology 299, 4-14.

Chaplot, V.A.M., Le Bissonnais, Y., 2003. Runoff features for interrill erosion at different rainfall intensities, slope lengths, and gradients in an agricultural loessial hillslope. Soil Science Society of America Journal 67, 844-851.

Chen, H., Cai, Q.G., 2006. Impact of hillslope vegetation restoration on gully erosion induced sediment yield. Science in China Series D-Earth Sciences 49, 176-192. de Vente, J., Poesen, J., 2005. Predicting soil erosion and sediment yield at the basin scale: scale issues and semi-quantitative models. Earth-Science Reviews 71, 95-125.

Descheemaeker, K., Nyssen, J., Poesen, J., Raes, D., Haile, M., Muys, B., Deckers, S., 2006. Runoff on slopes with restoring vegetation: a case study from the Tigray highlands, Ethiopia. Journal of Hydrology 331, 219-241.

Descroix, L., Barrios, J.L.G., Viramontes, D., 2008. Gully and sheet erosion on subtropical mountain slopes: their respective roles and the scale effect. Catena 72, 325-339.

Dunjó, G., Pardini, G., Gispert, M., 2004. The role of land use-land cover on runoff generation and sediment yield at a microplot scale, in a small Mediterranean catchment. Journal of Arid Environments 57, 239-256.

Fang, H.Y., Cai, Q.G., Chen, H., Li, Q.Y., 2008. Effect of rainfall regime and slope on runoff in a gullied loess region on the Loess Plateau in China. Environmental Management 42, 402-411.

Fryirs, K.A., Brierley, G.J., Preston, N.J., Kasai, M., 2007. Buffers, barriers and blankets: the (dis)connectivity of catchment-scale sediment cascades. Catena 70, 49-67.

Gilley, J.E., Risse, L.M., 2000. Runoff and soil loss as affected by the application of manure. Transactions of ASAE 43, 1583-1588.

Gomi, T., Sidle, R.C., Miyata, S., Kosugi, K., Onda, Y., 2008. Dynamic runoff connectivity of overland flow on steep forested hillslopes: scale effects and runoff transfer. Water Resource Research 44, W08411. doi:10.1029/2007WR005894

He, X., Tang, K., Zhang, X., 2004. Soil erosion dynamics on the Chinese Loess Plateau in the last 10,000 years. Mountain Research and Development 24, 342-347.

Huang, M.B., Zhang, L., Gallichand, J., 2003. Runoff responses to afforestation in a watershed of the Loess Plateau, China. Hydrological Processes 17, 2599-2609.

Jiao, J., Wang, W., Hao, X., 1999. Precipitation and erosion characteristics of rain-storm in different pattern on Loess Plateau. Journal of Arid Land Resources and Environment $13,34-42$.

Jiao, J.Y., Tzanopoulos, J., Xofis, P., Bai, W.J., Ma, X.H., Mitchley, J., 2007. Can the study of natural vegetation succession assist in the control of soil erosion on abandoned croplands on the Loess Plateau, China? Restoration Ecology 15, 391-399.

Kirkby, M., 2001. Modelling the interactions between soil surface properties and water erosion. Catena 46, 89-102.

Kirkby, M., Bracken, L., Reaney, S., 2002. The influence of land use, soils and topography on the delivery of hillslope runoff to channels in SE Spain. Earth Surface Processes and Landforms 27, 1459-1473.

Li, G., Liang, W., Yang, Q.K., 2009. Analysis of land use pattern change in coarse sandy region of middle reaches of Yellow River. Science of Soil and Water Conservation 7 (3), 52-58 (in Chinese).

Li, P., Li, Z., Zheng, L., 2004. Effect of vegetation at preliminary succession stages on soil infiltration and runoff under simulating rainfall. Journal of Soil and Water Conservation 18, 54-62 (in Chinese)

Li, Y.Y., Shao, M.A., 2006. Change of soil physical properties under long-term natural vegetation restoration in the Loess Plateau of China. Journal of Arid Environment 64, 77-96.

Li, Y., Yang, J., Zhu, Y., Chen, J., Wu, S., Li, G., Ma, Q., 1997. Using ${ }^{137} \mathrm{Cs}$ and ${ }^{210} \mathrm{~Pb}$ to assess the sediment sources in a dam reservoir catchment on the Loess Plateau, China. China Nuclear Science and Technology Report S1, 2-15 (in Chinese).

Li, Y., Poesen, J., Yang, J.C., Fu, B., Zhang, J.H., 2003. Evaluating gully erosion using ${ }^{137} \mathrm{Cs}$ and ${ }^{210} \mathrm{~Pb} /{ }^{137} \mathrm{Cs}$. Soil \& Tillage Research 69, 107-115.

Lian, G., Guo, X.D., Fu, B.J., Hu, C.X. 2006. Spatial variability of bulk density and soil water in a small catchment of the Loess Plateau. Acta Ecologica Sinica 26, 647-654 (in Chinese).

Lichner, L., Orfánus, T., Nováková, K., ŠíR, M., Tesař, M., 2007. The impact of vegetation on hydraulic conductivity of sandy soil. Soil \& Water Resource 2, 59-66.

Liu, C.L., Shao, M.A., 2008. Soil hydraulic properties and their influences on soil water content under different land uses in Liudaogou watershed of the Loess Plateau. Chinese Journal of Applied Ecology 19, 2400-2407 (in Chinese).

Liu, G.S., Jiang, N.H. Zhang, L.D. Liu, Z.L., 1996. Soil Physical and Chemical Analysis and Description of Soil Profile. China Standardization Publishing House, Beijing (in Chinese).

Liu, G., 1997. Vegetation restoration and improvement process of soil anti-scourability in Loess Plateau, II. Improvement of soil anti-scourability during vegetation restoration. Research of Soil and Water Conservation 4,111-121 (in Chinese).

Llorens, P., Domingo, F., 2007. Rainfall partitioning by vegetation under Mediterranean conditions. A review of studies in Europe. Journal of Hydrology 335, 37-54.

Marques, M.J., Bienes, R., Jimenez, L., Perez-Rodriguez, R., 2007. Effect of vegetal cover on runoff and soil erosion under light intensity events: rainfall simulation over USLE plots. The Science of the Total Environment 378, 161-165.

Mayor, Á.G., Bautista, S., Small, E.E., Dixon, M., Bellot, J., 2008. Measurement of the connectivity of runoff source areas as determined by vegetation pattern and topography: a tool for assessing potential water and soil losses in drylands. Water Resources Research 44, W10423. doi:10.1029/2007WR006367.

Ministry of Water Resources of P.R. China, 2008. Standard for Classification and Gradation of Soil Erosion SL 190-2007. China Waterpower Press, Beijing (In Chinese).

Molina, A., Govers, G., Van den Putte, A., Poesen, J., Vanacker, V., 2009. Assessing the reduction of the hydrological connectivity of gully systems through vegetation restoration: field experiments and numerical modelling. Hydrology and Earth System Sciences 13, 1823-1836.

Molina, A., Govers, G., Vanacker, V., Poesen, J., 2007. Runoff generation in a degraded Andean ecosystem: interaction of vegetation cover and land use. Catena 71, 357-370.

Moreno-de las Heras, M., Nicolau, J.M., Merino-Martin, L., Wilcox, B.P., 2010. Plot-scale effects on runoff and erosion along a slope degradation gradient. Water Resources Research 46, W04503. doi:10.1029/2009WR007875.

Nearing, M.A., Jetten, V., Baffaut, C., Cerdan, O., Couturier, A., 2005. Modeling response of soil erosion and runoff to changes in precipitation and cover. Catena 61,131-154.

Neave, M., Rayburg, S., 2007. A field investigation into the effects of progressive rainfall-induced soil seal and crust development on runoff and erosion rates: the impact of surface cover. Geomorphology 87, 378-390. 
Qiu, L.P., Zhang, X.C., Cheng, J.M., Han, X.N., 2009. Effects of 22 years of revegetation on soil quality in the semi-arid area of the Loess Plateau. African Journal of Biotechnology 8 , 6896-6907.

Quine, T.A., Walling, D.E., Zhang, X., 1999. Tillage erosion, water erosion and soil quality on cultivated terraces near Xifeng in the Loess Plateau, China. Land Degradation \& Development 10, 251-274.

Ran, D.C., Gao, J.L., Zhao, A.Z., Wang, Y.C., 2003. Analysis on runoff and sediment characteristics and management policies in Huangfuchuan watershed. Journal of Hydraulic Engineering 34 (1), 122-128 (in Chinese).

Ren, M.E., Shi, T.L., 1986. Sediment discharge of the Yellow River China and its effect on the sedimentation of the Bohai and the Yellow Sea. Continental Shelf Research 6, 785-810.

Rey, F., 2004. Effectiveness of vegetation barriers for marly sediment trapping. Earth Surface Processes and Landforms 29, 1161-1169.

Scott, D.F., Smith, R.E., 1997. Preliminary empirical models to predict reductions in total and low flows resulting from afforestation. Water SA 23, 135-140.

Scott, D.F. Le, Maitre, D.C., Fairbanks, D.H.K., 2000. Forestry and streamflow reductions in South Africa: a reference system for assessing extent and distribution. Water SA 24, 187-199.

Shi, H., Shao, M.G., 2000. Soil and water loss from the Loess Plateau in China. Journal of Arid Environments 45, 9-20.

Soil Survey Division Staff, 1993. Soil survey manual. Soil Conservation Service: U.S. Department of Agriculture Handbook, 18.

Sun, G., Zhou, G., Zhang, Z., Wei, X., 2006. Potential water yield reduction due to forestation across China. Journal of Hydrology 328, 548-558.

Thompson, S.E., Harman, C.J., Heine, P., Katul, G.G., 2010. Vegetation-infiltration relationships across climatic and soil type gradients. Journal of Geophysical Research 115, G02023. doi:10.1029/2009JG001134.

Valentin, C., Poesen, J., Li, Y., 2005. Gully erosion: impacts, factors and control. Catena 63, 132-153.

Van Dessel, W., Van Rompaey, A., Poelmans, L., Szilassi, P., 2008. Predicting land cover changes and their impact on the sediment influx in the Lake Balaton catchment. Landscape Ecology 23, 645-656.

Van Rompaey, A., Krasa, J., Dostal, T., 2007. Modelling the impact of land cover changes in the Czech Republic on sediment delivery. Land Use Policy 24, 576-583.

Wang, L., Shao, M., Wang, Q.J., Gale, W.J., 2006. Historical changes in the environment of the Chinese Loess Plateau. Environmental Science \& Policy 9, 675-684.

Wang, W.Z., Jiao, J.Y., 2002. Temporal and spatial variation features of sediment yield intensity on the Loess Plateau. Acta Geographica Sinica 57, 210-217 (in Chinese).

Wang, Y., Fu, B., Chen, L., Lu, Y., Luo, C., 2009. Effect of land use change on soil erosion intensity in small watershed of Loess Hilly Region: a quantitative evaluation with 137-Cesium tracer. Chinese Journal of Application Ecology 20, 1571-1576 (in Chinese).

Wang, Y.H., Yu, P.T., Xiong, W., Shen, Z.X., Guo, M.C., Shi, Z.J., Du, A., Wang, L.M., 2008 Water-yield reduction after afforestation and related processes in the semiarid Liupan Mountains, Northwest China. Journal of the American Water Resources Association 44, 1086-1097.

Wang, Y.Z., Chang, Q.R., Qu, J., Meng, Q.X., 2010. Assessment on ecological effect of land use/cover changes on the Loess Plateau of North Shaanxi Province. Bulletin of Soil and Water Conservation 30, 134-137 (in Chinese).

Wei, W., Chen, L.D., Fu, B.J., Huang, Z.L., Wu, D.P., Gui, L.D., 2007. The effect of land uses and rainfall regimes on runoff and soil erosion in the semi-arid loess hilly area, China. Journal of Hydrology 335, 247-258.

Wen, Z., Jiao, F., Liu, B., Bu, Y., Jiao, J., 2005. Natural vegetation restoration and soil nutrient dynamic of abandoned farmlands in forest-steppe zone in Loess Plateau. Chinese Journal of Applied Ecology 16, 2025-2029 (in Chinese).

Wilcox, B.P., Breshears, D.D., Allen, C.D., 2003. Ecohydrology of resource-conserving semiarid woodland: effects of scale and disturbance. Ecological Monographs 73, 223-239.
Wischmeier, W.H., Smith, D.D., 1978. Predicting rainfall erosion losses: a guide to conservation planning. USDA-ARS Agriculture Handbook No. 537, Washington DC.

Xin, Z.B., Xu, J.X., Zheng, W., 2008. Spatiotemporal variations of vegetation cover on the Chinese Loess Plateau (1981-2006): impacts of climate changes and human activities. Science in China Series D-Earth Sciences 51, 67-78.

Xing, J.X., Guo, J.Y., Zhao, X.H., Lan, D.M., 2010. Research on soil physical properties after conversion of cropland to forest in the Loess Hilly Region-taking example of Wuqi county. Journal of Inner Mongolia Agricultural University 31, 41-46 (in Chinese).

$\mathrm{Xu}$, J.X., 2003. Sediment flux to the sea as influenced by changing human activities and precipitation: example of the Yellow River, China. Environmental Management 31 328-341.

Xu, J.X., Yan, Y.X., 2005. Scale effects on specific sediment yield in the Yellow River basin and geomorphological explanations. Journal of Hydrology 307, 219-232.

Xu, X.L., Ma, K.M., Fu, B.J., Song, C.J., Liu, W., 2008. Influence of three plant species with different morphologies on water runoff and soil loss in a dry-warm river valley, $\mathrm{SW}$ China. Forest Ecology and Management 256, 656-663.

Yair, A., Raz-Yassif, N., 2004. Hydrological processes in a small and catchment: scale effects of rainfall and slope length. Geomorphology 61, 155-169.

Yu, G.Q., Li, Z.B., Zhang, X., Li, P., Chen, L., Jia, L.L., 2009. Experimental study on runoff and sediment yield under field simulated rainfall condition. Journal of Soil and Water Conservation 23 (4), 10-14 (in Chinese)

Zhang, L., Dawes, W.R., Walker, G.R., 2001. Response of mean annual evapotranspiration to vegetation changes at catchment scale. Water Resource Research 37, 701-708.

Zhang, M., Liu, J., 2010. Controlling factors of loess landslides in western China. Environmental Earth Sciences 59, 1671-1680.

Zhang, S.L., Grip, H., Lovdahl, L., 2006. Effect of soil compaction on hydraulic properties of two loess soils in China. Soil \& Tillage Research 90, 117-125.

Zhang, X., Gao, Z., Zhang, L., Li, R., 2007. Responses of runoff to vegetation alteration a different temporal scale. Science of Soil and Water Conservation 5, 94-100 (in Chinese).

Zhang, X., Quine, T.A., Walling, D.E., 1998. Soil erosion rates on sloping cultivated land on the Loess Plateau near Ansai, Shaanxi Province, China: an investigation using 137Cs and rill measurements. Hydrological Processes 12, 171-189.

Zhang, X.M., Cao, W.H., Guo, Q.C., Wu, S.H., 2010. Effects of landuse change on surface runoff and sediment yield at different watershed scales on the Loess Plateau. International Journal of Sediment Research 25, 283-293.

Zhang, X.P., Zhang, L., McVicar, T.R., Van Niel, T.G., Li, L.T., Li, R., Yang, Q.K., Wei, L., 2008 Modeling the impact of afforestation on average annual streamflow in the Loess Plateau, China. Hydrological Processes 22, 1996-2004.

Zheng, F., 2005. Effect of accelerated soil erosion on soil nutrient loss after deforestation on the Loess Plateau. Pedosphere 15, 707-715.

Zheng, F., 2006. Effect of vegetation changes on soil erosion on the Loess Plateau. Pedosphere 16, 420-427.

Zheng, F., Tang, K.L., Bai, H.Y., 1994. Study on sediment yield from slope and gully erosion after reclamation of forestland. Soil \& Water Conservation in China 8, 19-20 (in Chinese).

Zhou, P., Liu, G., Hou, X., 2008. Study on vegetation and soil nutrient characters of Artemisia sacrorum communities in hilly-gully region of the loess plateau. Acta Pratacultrae Sinica 17, 9-18 (in Chinese).

Zhou, Z.C., Shangguan, Z.P., Zhao, D., 2006. Modeling vegetation coverage and soil erosion in the Loess Plateau Area of China. Ecological Modeling 198, 263-268.

Zhu, B.B., Li, Z.B., Li, P., Liu, G.B., Xue, S., 2010. Soil erodibility, microbial biomass, and physical-chemical property changes during long-term natural vegetation restoration: a case study in the Loess Plateau, China. Ecological Research 25, 531-541.

Zuazo, V.H.D., Pleguezuelo, C.R.R., 2008. Soil-erosion and runoff prevention by plant covers: a review. Agronomy for Sustainable Development 28, 65-86. 